\title{
White Light - White Heat \\ The use of Fire as a Light and Heat Source in an Atrium House in Roman Pompeii
}

\author{
Henrik Boman
}

\begin{abstract}
This article concerns the distribution of fire as light and heat source within the insula investigated by the ongoing Swedish Pompeii Project. Here the author suggests that fire installations as kitchens, ovens and baths were clustered in specific areas within this insula, and the installations were not efficiently used to heat the dwelling areas of the house.

It is also proposed that the surfaces of the interior walls and floors of the Roman atrium house were polished in purpose to reflect and distribute light and, which is emphasised in the article, to soften the transition between brightly lit areas and areas in dark shadow. This contrast had to be eliminated for the human eye to adopt to the light conditions in the room and by that, to make the light as efficient as possible.
\end{abstract}

Henrik Boman, Department of Classical Archaeology and Ancient History, University of Stockholm, SE-106 91 Stockholm, Sweden.

Key words: Pompeii, light, lamps, fire, kitchen, hearth.

The aim of this article is to present a preliminary synthesis of the use of fire in an insula in Roman Pompeii. Stationary installations for fire, such as kitchens, ovens and baths within the insula $\mathrm{V} 1$, are examined in the study. By setting their distribution in relation to the areas supplied with natural light and areas where portable objects (oil lamps and braziers) were needed, an alternative suggestion emerges for the appearance of a Roman atrium house.

Together with Dr. Monica Nilsson, the author of this article is responsible for the documentation of the buildings Caupona (V 1,13), the 'bakery' (V 1,15) and the Tavern (V 1,20-21 $)^{1}$ in the insula, which were investigated by the Swedish Pompeii Project in 2000-2004. The project has so far processed the northern twothirds of the insula, and the work is still in progress. ${ }^{2}$

\footnotetext{
${ }^{1}$ The houses were designated addresses by the excavator G. Fiorelli in the $19^{\text {th }}$ century by dividing the site into 9 regions (Regiones I-IX). These regiones were further divided into blocks (insulae) after the street grid, each insula with a number in Arabic letters, and then each doorway was assigned a number in successive order along the course of the streets (Fiorelli 1875:22-25; Cooley 2003:88-89).

${ }^{2}$ The project is based at the Stockholm university and at the Swedish Institute in Rome. Prof. Anne-Marie Leander Touati is the director, Dr. Margareta Staub Gierow the field director, and Doc. Arja Karavieri the director of excavations. Responsible for the publication are Dr. Margareta Staub Gierow, Doc. Arja Karavieri, Dr. Reneé Forsell, Dr. Henrik Boman and Dr. Monica Nilsson.
} 
The aim of the project is to document and make a systematic analysis of the complete insula V 1 in the proximity of Porta Vesuvio. This part of the insula was excavated in the $1870 \mathrm{~s}$ by Giuseppe Fiorelli and August Mau. (Reports were published after each campaign in $B d I, N S c$ and $G d S$. Modern documentation of the standing remains is found in CTP 1986 and $P P M$.) The publications remain incomplete especially concerning plans, architectural drawings and overall analysis.

Insula V 1 consists of three large atrium-peristyle houses: Casa degli Epigrammi greci (V 1,18); Casa di Caecilius Iucundus (V 1,26) with an adjoining house (V 1,23). and Casa del Torello (V 1,17). Three smaller atrium houses, two of which lack a garden peristyle: Casa di Tofelanus Valens (V 1,28) and V 1,3 which might have been part of the Torello estate (V 1,7) in the last phase, and the 'bakery' (V 1,15). There are also two large thermopolia ( $\mathrm{V} 1,13$ and $\mathrm{V} \mathrm{1,1.32)}$ as well as a number of smaller shops and taverns of which some are connected to the houses behind them (Fig. 1).

It is important to clarify that the examples used in this article are dated to the very last days of Pompeii when the eruption of Vesuvius was imminent (Descoeudres 1993:166-168; Cooley 2003:26-35. For the ancient source, see Cooley \& Cooley 2004:27-31).

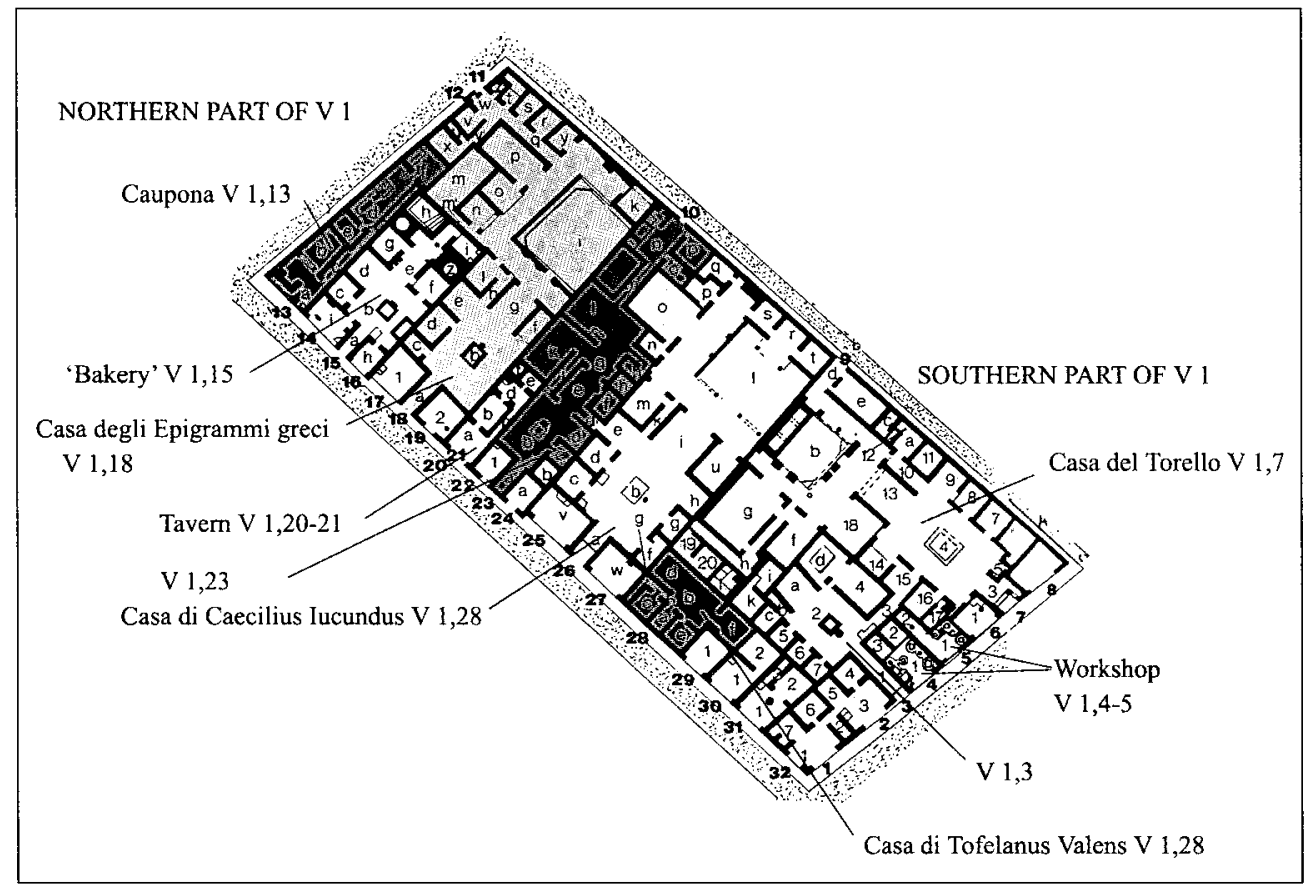

Fig. 1. Pompeii, Insula V 1. Based on CTP IIIA, pp. 70 and PPM Vol. 3, pp. 553. 


\section{FIRE AND HEAT IN ROMAN ANTIQUITY}

In Insula V 1, fire was used for light, heat and semi-industrial manufacturing. We find three specific types of areas with stationary installations for fire within the insula V 1: kitchens with hearths, ovens and baths. Portable braziers were used for cooking and for heating the rooms.

The Pompeian hearth was an open rectangular construction of varying height, massive as in all cases in Insula V 1, or with supporting arches for storage underneath (Salza Prina Ricotti 1978:239-273; Faas 2003:131). Wood or charcoal was burnt on open, flat, stone hearths with a raised edge, and grills and pans were used for cooking on stands above the fire (Fig. 2). The smoke was let out through small windows in the walls or through holes in the roof, and there were rarely specific chimneys since the fire in these hearths burned in open air. There could also be small ovens in connection with these hearths, as in room t in Casa degli Epigrammi greci (V 1,18) and Casa Grande (VII 14,5.17-19).

\section{The kitchens}

In the investigated northern part of Insula V 1, we find kitchens with hearths at three locations: in the rear room of Caupona (V 1,13), in the back area of Casa degli Epigrammi greci $(\mathrm{V} 1,18)$ and in the annex (V 1,23) to Casa di Caecilius Iucundus (Fig. 3). At least the first of these hearths is heavily restored after the excavations, but the general appearance is consistent with what we know about hearths from elsewhere. In room i in the 'bakery' we have found foundations of what could have been a hearth, and in the Tavern (V 1,20-21) the excavation reports mention a hearth which today is completely destroyed ( $B d I$ 1877:17-18). Further, during the excavations in the 1870 s there were observations of a small hearth close to the street in the front taverna in $\mathrm{V} \mathrm{I,13.} \mathrm{According} \mathrm{to} \mathrm{the} \mathrm{reports} \mathrm{of}$ this tavern, the stone hearth was substituted for a lead container for the burning material. Nothing remains today of this installation except for the round window which was interpreted as a smoke outlet by the excavators ( $B d I$ 1877:135). This construction can represent the portable, or semi-portable, objects for heating food. Similar small structures could have existed at several places in the surrounding compartments, although so far, we have not found any traces of them.

Although less well investigated, it is necessary to bring the southern part of the insula into the discussion. We can conclude that there is a large kitchen

Fig. 2. Kitchen in Caupona V 1,13, room $f$. The hearth was restored after the excavation of 1875. Photo: Henrik Boman.

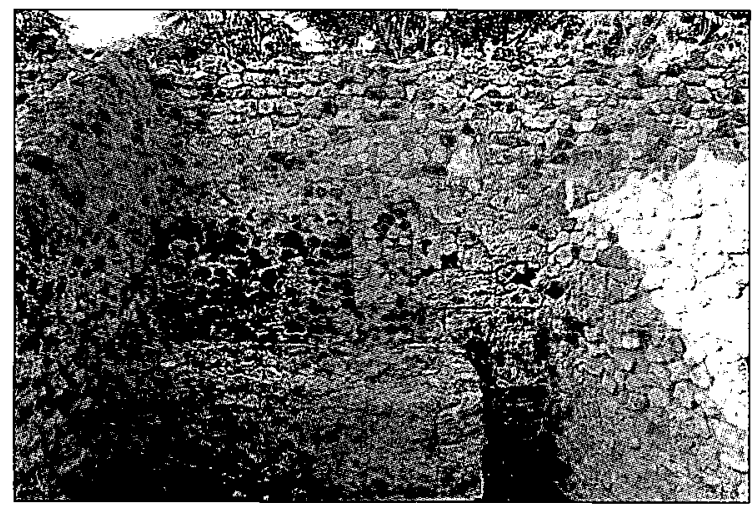




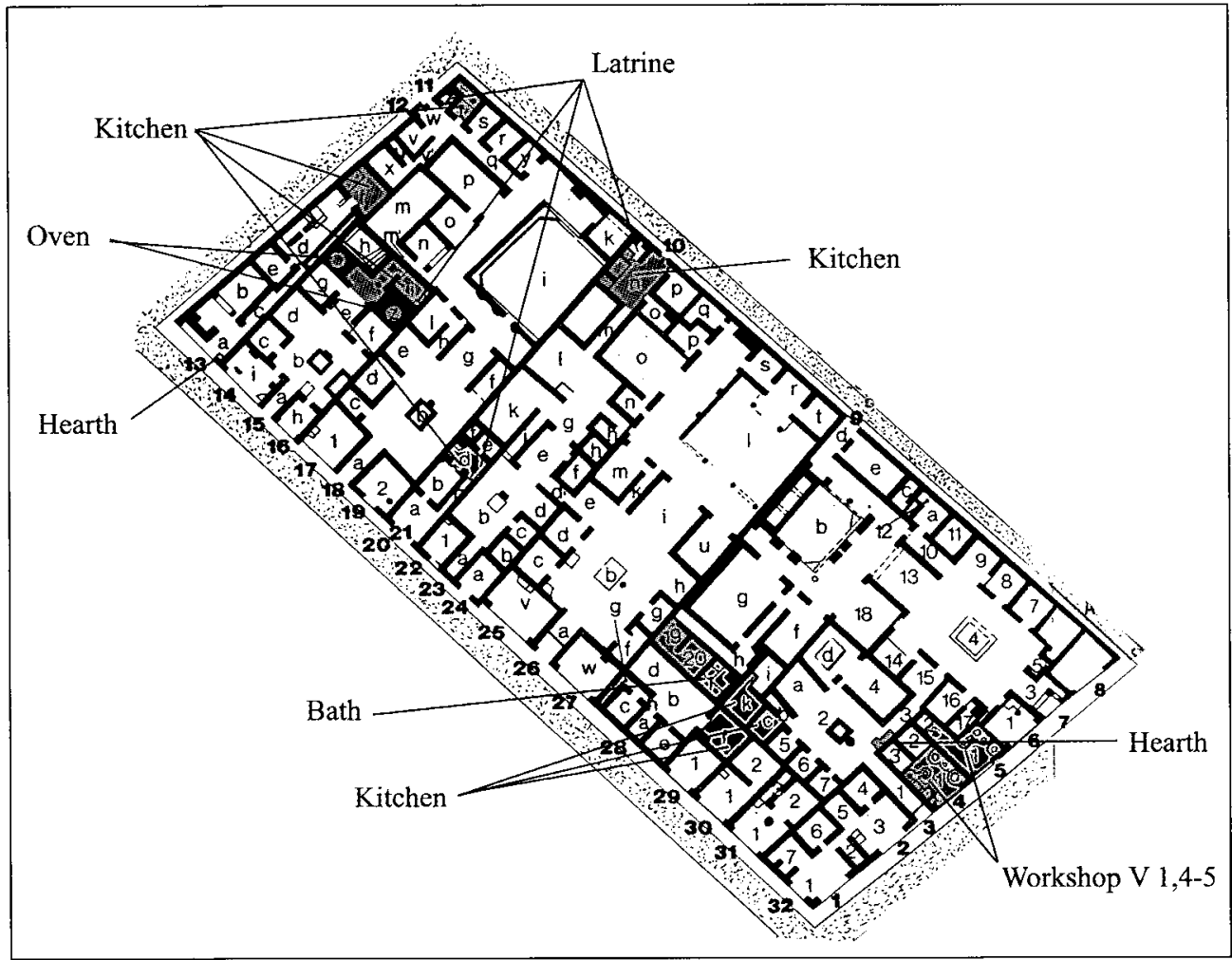

Fig. 3. Insula $V 1$ with the distribution of fire installations and latrines in connection with these hearths (latrines in southern part not marked). Based on CTP IIIA, pp. 70 and PPM Vol. 3, pp. 553.

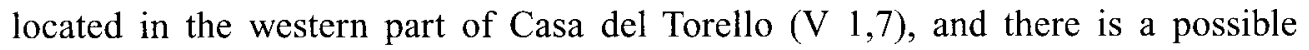
kitchen in the adjacent room of Casa di Tofelanus Valens (V 1,28) (Overbeck \& Mau 1884:271; Eschebach 1993:128). Eschebach identifies a hearth in the atrium of V 1,3 as a kitchen (Eschebach 1993:123-124, 128), though its location indicates a domestic altar (Salza Prina Ricotti 1978:240, fig. 2, 249-255; Foss 1994:69-73; Foss 1997:202, 217-218; Faas 2003:50-52), another category of fire installation. In V 1,3 there is a possible hearth in a room to the NW of the atrium (Fig. 3). In the thermopolium in the SW corner of the insula, a minor installation for heating food is found in association with the counter (Eschebach 1993:122). Further investigations in this part of the insula are necessary for a full documentation of the distribution of fire.

Industrial manufacturing: ovens and the 'bakery'

Within insula $\mathrm{V} 1$ the industrial activities, i.e., production that required special installations, can be found in two areas: the 'bakery' (V 1,15) in the northern part of the insula; and the workshop of a dyer (V 1,4 and V 1,5) along Via di Nola (Jongman 1988:166; Laurence 1994: 61-64).

We will take a closer look at the installation in the 'bakery' (V 1,15). The 


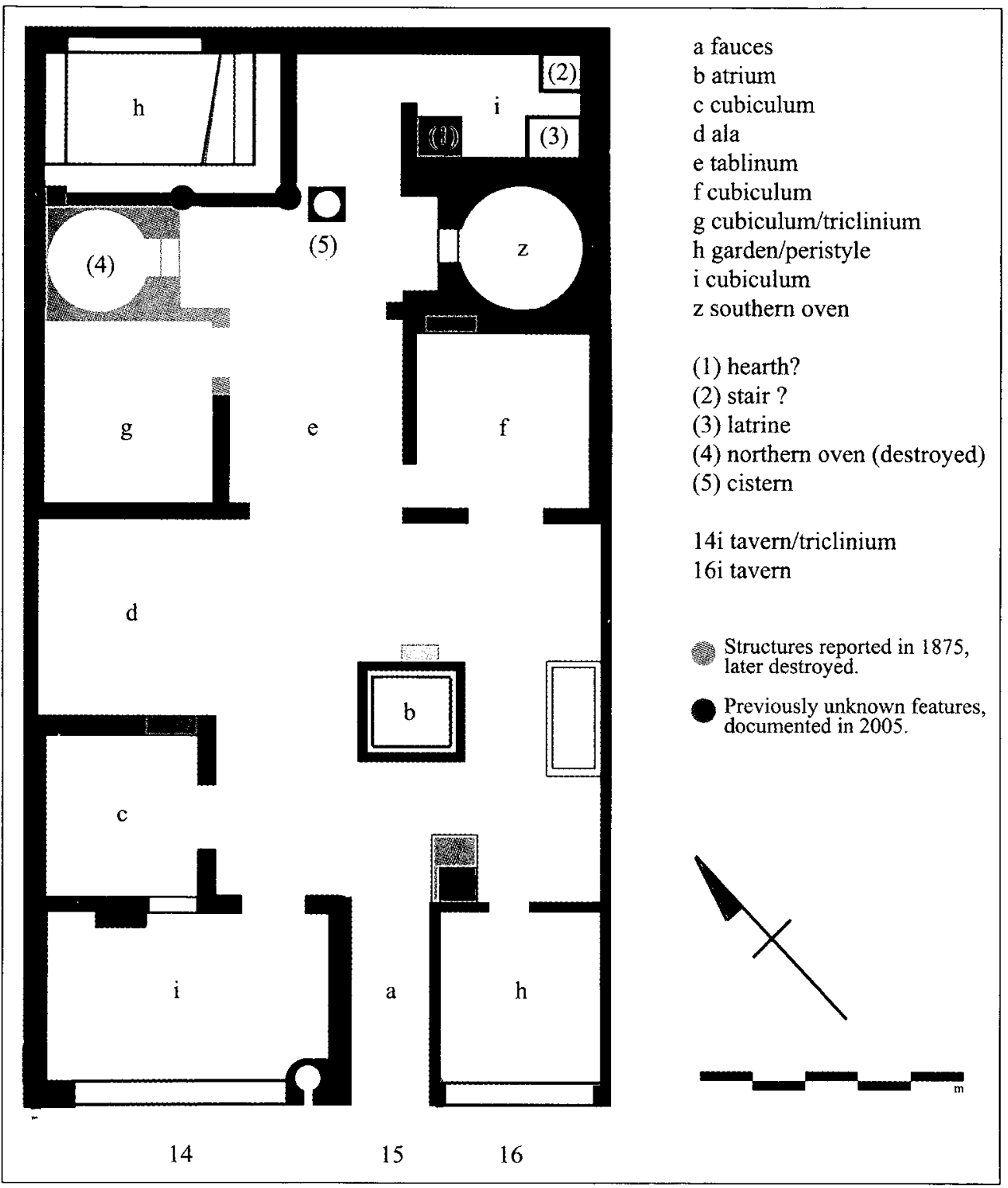

Fig. 4. 'Bakery'V 1, 15. Preliminary plan established 2005. By Henrik Boman.

house was originally an atrium house of medium size, with a small garden peristyle. The two ovens close to the peristyle were constructed in the late history of the house (Fig. 4).

The ovens were placed under the roof of the peristyle, close to the open garden area of the peristyle. How the roof was constructed over the ovens is still a matter of debate. We have not yet identified any beam holes in the walls or other supporting structures for the roof except for two columns and a pilaster connected to the colonnade around the open area of the peristyle. There are remains of a 
staircase in room $\mathrm{i}$, though it could belong to the early phase of the building, and the second floor may have been removed when the ovens were constructed due to the risk of fire.

The 'bakery' (V 1,15) is one of few facilities found in Pompeii with two ovens ( $B d I$ 1876:132; Mayeske 1972). The northern oven was completely destroyed by a bomb during the Second World War when the allied air forces attacked Pompeii in late 1943 (Maiuri 1950:199-211).

The southern oven is still in a good state of preservation, though the upper part is destroyed.

This oven is fit into a pre-existing room in the southern area of the peristyle. We can still see parts of the old lava stone wall of this room that preceded the oven facade (Fig. 5).

We can conclude that the preserved oven is an elaborated form of oven, though it differs in several ways from other baker's ovens (Mau 1886; Frayn 1978; Mayeske 1979:40-41; Curtis 2001). Half a dolium (large storage vessel) was added to the domed smoke chamber, which created a double domed smoke chamber (Fig. 6). The top of the oven is destroyed, and we do not know whether there was an opening at the top or not. Further, the domed smoke chamber is significantly flatter compared to other known baker's ovens in Pompeii. The opening to the smoke chamber is low $(\mathrm{c} .0 .35 \mathrm{~m})$ compared to other preserved ovens in which the opening is often about 0.5 $\mathrm{m}$ high (Strocka 1991:60-62, figs. 435-436).

We can only deduce information about the size of the destroyed oven, since nothing is said about its appearance in the excavation report ( $B d I$ 1877:129134). In the plans published after 1875 , we can see that the oven occupied the northern intercolumnium of the peristyle. This gives the oven the same width as the peristyle, c. $1.8 \mathrm{~m}$, and this oven must have been considerably smaller than the preserved oven (which has a diameter of c. $2.8 \mathrm{~m}$ ).

\section{Conclusion}

We can see that the major hearths in the northern part of the insula are all located along the north and east streets of the insula, in the rear of the buildings and close

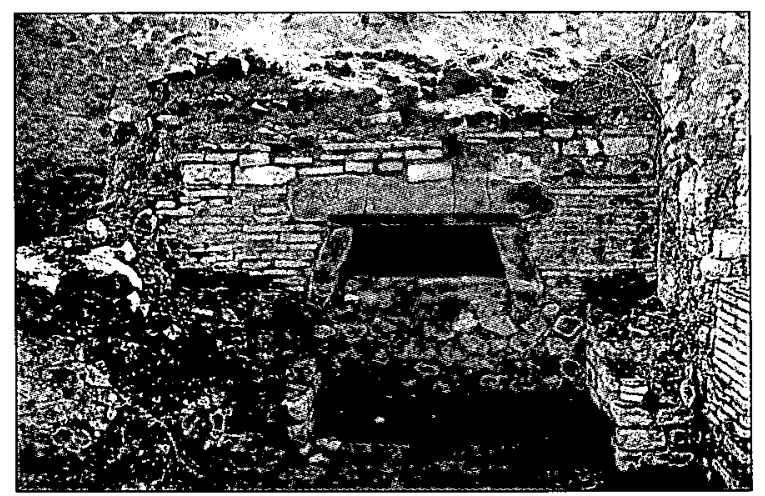
to the exterior walls of the insula. The fire from two of them (V 1,13 and V 1,11-12) heated the walls towards the street. In V 1,23 the hearth abuts the wall of the peristyle of the neighbouring house $\mathrm{V} \mathrm{1,18.} \mathrm{Thus}$

Fig. 5. 'Bakery' $V$ 1, 15. The front of the southern oven ( $z$ ) after the cleaning of debris from the bomb in 1943. Photo: Henrik Boman. 


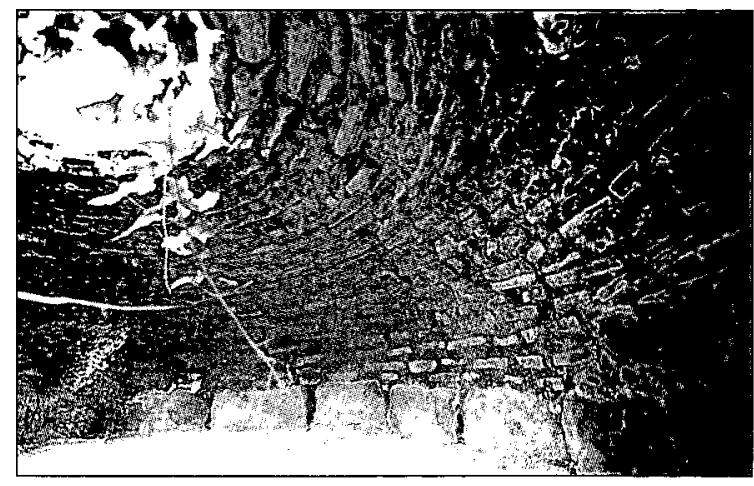

Fig. 6. Bakery V 1,15. Southern oven (z). interior: Photo: Henrik Boman.

used for cooking, none of the hearths were situated so as to heat the surrounding rooms, as a fireplace and a chimney in a modern farmhouse would have done.

In the southern part, the brief survey showed that the major kitchens are located in the interior of the insula, though clustered together in a limited area and more or less wall to wall. The kitchens in V 1,3 and Valens house (V 1,28) are placed in close relation to the kitchen area in Casa del Torello. It is important to note that these fire installations are located close to the substantial construction of the heating system for the private baths of Casa del Torello. This may signify a need to control fire by concentrating its use to a limited area.

The location of the northern oven is important from the aspect of fire and heat. The oven was placed at the wall towards the Caupona (V 1,13). There is a difference in floor level between the two buildings (the Caupona is c. $1.2 \mathrm{~m}$ higher) and the room in the Caupona that corresponds to the location of the oven is an open court. This location is a parallel to that of the hearths discussed above; the heat from the northern oven was only used to a limited extent for heating the surrounding rooms.

The appearance of room $g$ in the 'bakery' was changed when the northern oven sealed the large window that previously opened to the peristyle in this room. In its early phase the room could be associated with a triclinium (dining room) with a view towards the garden. After the construction of the oven, the room was heated by the fire, but the walls were covered with a crude grey plaster, and therefore the earlier function of the dining room probably had ceased.

We can conclude that the stationary installations for food preparation did not have the combined function of heating the dwelling quarters of the houses. The kitchen areas are, as we have seen, located far from the major rooms of the atrium house. The surrounding rooms may have received some heat, though the location towards the outer walls caused most of the heat to radiate out from the insula.

We can further note that these installations are all located close to a water source, a cistern or other installations that needed water and possibilities to dispose of water, mainly the latrine. In connection with 4 of 5 hearths in the northern part of the insula, we find latrines; in 3 of 5 we find a cistern close to or in the proximity of the hearth. This combination of latrine and hearth can be observed frequently in the kitchen areas in other insulae in Pompeii (Salza Prina Ricotti 1978:244245; Jansen 1997:128). We can see the same connection to water in the southern part of the insula. In Casa del Torello the kitchen is located by the bath where 
water is abundant, and in Casa di Tofelanus Valens a cistern was observed by the excavators.

Further, in the peristyle of the 'bakery' we found a cistern, which predates the ovens, where water from the peristyle was collected. We can clearly place the use of fire in the ovens in the same context with water as the kitchens discussed above. We can therefore assume that the open space of the peristyle, which supplied the fire in the ovens with air and let the smoke out, and the presence of water for use in the manufacturing and for fire safety were important factors in the choice of constructing the ovens at these locations. The placing of the ovens is largely similar to the placing of the hearths.

We can assume that the combination of fire and water was important for fire safety. So was the placing of kitchens in connection to the outer walls or blind walls of peristyles, as well as the clustering of kitchens with fire systems of the private baths. This might be an indication of an arrangement to reduce the risk of fire, but it also minimises the use of heat from the hearths for the surrounding rooms.

It is important to note that the arrangement of the upper floor is not taken into consideration here. Most of the kitchens seem to have an upper storey, and to investigate the scanty evidence of the upper floor is an interesting topic for further work in the field of fire usage.

\section{Heating of rooms - the baths and braziers}

The baths in Casa del Torello have a hypocaust system; it consists of a floor raised on brick piers with a furnace that heated the air that circulated under the floor and up the hollow walls through brick conduits (Ring 1996:717, fig. 2; Yegül 1992:356-368). This hypocaust is the only elaborated system for heating rooms in the insula. As I mentioned earlier, the kitchen of Casa del Torello is located close to the bath. It seems that the installations for fire were concentrated to a specific area within the insula.

Braziers, primarily used as heaters and for food preparation (Hermansen 1974), must also have been a minor light source. The context of braziers shows that they were often used for food preparation in the peristyles. (Allison 2004:89-92, 98, 102-103). We have to remember that the eruption of Vesuvius was in late summer, and presumably braziers were not used for heating the rooms in this season. Further investigation of the braziers may shed more light on their use.

\section{ARTIFICIAL LIGHT}

With regard to fire, the conditions for light within the atrium house are essential to the perception of space (Rasmussen 1964:186-211; Brogan 1997; Plummer 1997). In the Roman house it is possible to structure the quality of light and heat in causal relationships of light/dark, warm/cold and open/closed, and the contradictions constitute the need for light and the need for heat inside the house.

The Roman house was constructed around two main architectural bodies lit 
by daylight: the atrium and the peristyle. The former can be classified as a closed space, and the latter as an open space (Packer 1975; Evans 1978; Hoffmann 1980; Laurence 1994; Nappo 1997; Wallace-Hadrill 1997; Dickmann 1997; Grahame 1997). If we observe the areas supplied with daylight we can see a pattern. In a densely built city like Pompeii the areas for using windows are few, and the atrium and the peristyle garden tend to be the main supply of daylight to the surrounding rooms. An overwhelming majority of the rooms within the insula open either directly to the atrium and the peristyle, or as in the case of the taverns, with large doors towards the street. We can say that the tablinum, located between the atrium and the garden, is the room in the house best supplied with natural light (Figs. 7-8).

From Insula V 1, the 'bakery', the atrium shows the arrangements of high doors to the rooms around. The doors are about $1.2 \mathrm{~m}$ wide and $3 \mathrm{~m}$ high, which is a significant height compared with the size of the room and which can be connected with the need for natural light. The openings had doors, as indicated by the thresholds, so it was possible to seal the room.

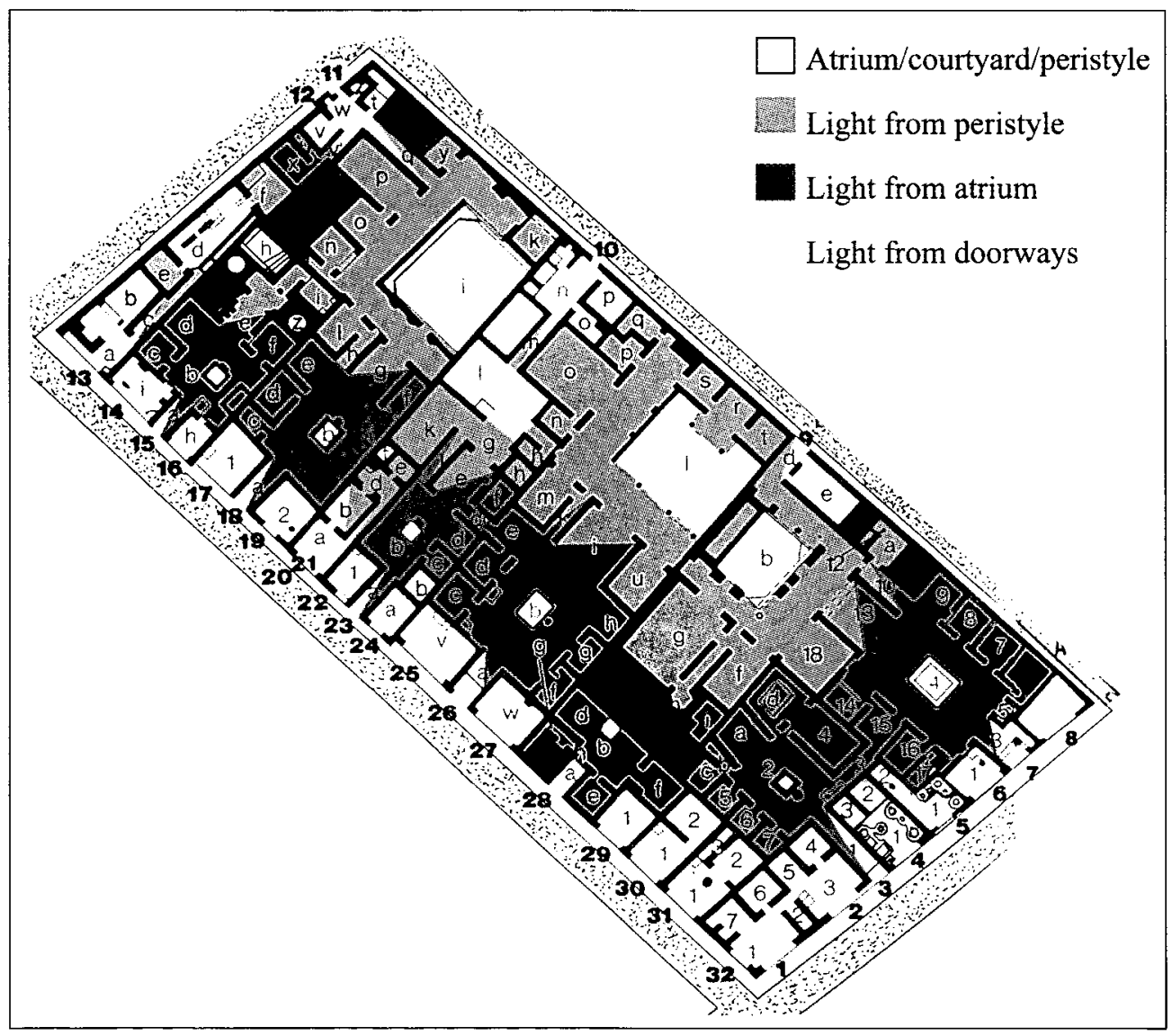

Fig. 7. Insula VI with the distribution of natural light. Based on CTP IIIA, pp.70 and PPM Vol. 3, pp. 553. 


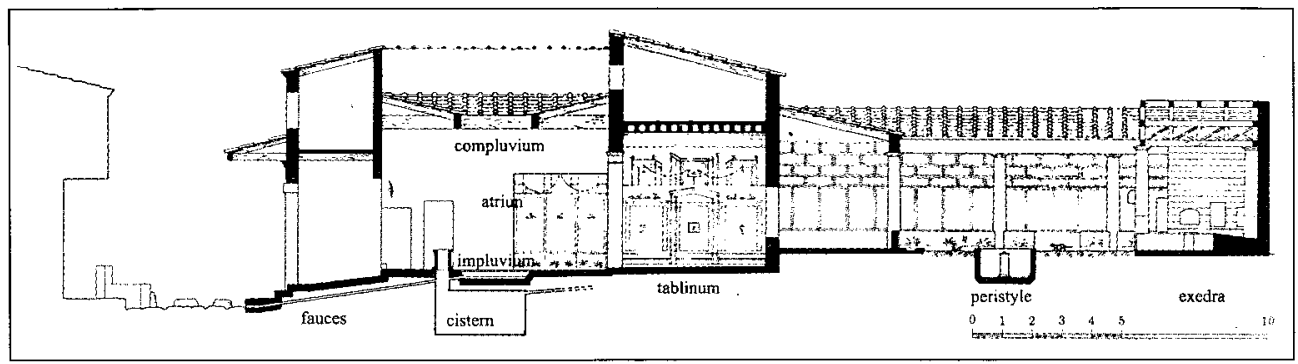

Fig. 8. Section of a house, with a two-floors atrium and a single-floor peristyle. Casa di Trebius Valens (III 2,1). Based on Adam 1994, fig. 691.

Thus, we can see that natural light was acquired mainly by large door openings inside the houses, a situation that contradicts the possibilities to sustain heat from fire. In an open space the light is let in and the heat escapes; to store generated heat, the space must be secluded and the light shut out. The use of lamps with an open flame, in combination with the draught from the natural light sources - i.e., open windows and doors - must have been a problem in the cold periods of the year. The open, natural, light source contradicted the warming of the rooms, and it also affected the use of artificial light in places where it was needed.

\section{Oil lamps}

The majority of movable light sources in a Roman house consist of oil lamps made of terracotta or metal. Bronze lanterns were also used, though these were exclusive in material and far less abundant than oil lamps. They could be placed in various locations - in workshops, private and public buildings, and in the streets (Radt 1986; Rickman Fitch \& Goldman 1994, xvii.). The oil lamps could be arranged one by one or in groups with various kinds of support, for example on tables, in niches or on high candelabra. Roman oil lamps are frequently found in archaeological contexts, and are usually seen as bulk material listed in catalogues from museums or sites (see Perlzweig 1961; Bailey 1980, Rickman Fitch \& Goldman 1994).

The oil lamps had an egg- or pear-shaped body with a small hole for pouring oil into the vessel and one or several nozzles for the wick. The wick was made of fibres of flax, wool, oakum, mullein, cotton or any other absorbent, long-strained material (Rickman Fitch \& Goldman 1994:21). The lamps could be decorated with moulded ornaments of pictorial representations.

The smoke from the burning oil could be reduced to almost nothing by the design of the nozzle (Bailey 1972:9; Bailey 1978; Rickman Fitch \& Goldman 1994:4-8, 21; Parisinou 1998). The efficiency of the flame was dependent on the size of the filling hole which let oxygen into the reservoir above the oil bowl, and on the size of the nozzle through which the oxygen was conducted (Rickman Fitch \& Goldman 1994:21). The lamps could produce more light if the wick was pulled forward, but the production of smoke was then increased. Brighter smoke- 
less light could only be produced by increasing the number of lamps or the number of nozzles on each lamp (Bailey 1972:9-10; Zhuravlev \& Zhuravleva 2002).

\section{Pattern of distribution}

As a rule, even in favourable conditions, there are problems with the find contexts in Pompeii (Dwyer 1982:14-16; Bon 1997). In several cases only the assemblage in a specific house is known, and not the exact find location within the house (Berry 1997:186-188; Allison 1999). The buildings of insula V 1, excavated quickly in the $1870 \mathrm{~s}$, generally lack information about the exact find context. For example, no lamps or lanterns are reported to have been found in the 'bakery' (V 1,15) or Tavern (V 1,20-21) ('bakery' (V 1,15); NSc 1876:27, 45; BdI 1877:120124; GdS 1877:252; GdS 1878:77-79. Taverna (V 1,20-21); GdS 3, 1877:254, 258; $B d I$ 1877:17-18). In Caupona (V 1,13) three supports for lamps and three lamps were found, but we do not know in which room ( $B d I$ 1877:135-138; $G d S$ $1877: 253-255$ ). This is a highly unlikely situation compared to the abundant finds of lamps in other buildings (Overbeck \& Mau 1884:203; Sperl 1990:63).

Provided with better find reports than the 'bakery' is a house $(18,14)$ of similar size studied by J. Berry. This house was excavated in 1938 and 1940-41. It comprised 11 rooms containing 23 lamps. In addition to these lamps, three candelabra were reported, each in separate rooms. Even here, we can say that the number of lamps and candelabra are few for such a large house, no more than four in each room, including the atrium. There are no lamps reported from the largest room (room 4), which may seem strange (Berry 1997:189-192).

The results from House $(18,14)$ can be used as a guide to a distributional pattern for artificial light sources. We can conclude that oil lamps were used to an equal extent in all rooms, and due to the limited light effect of the lamps, only a minor part of a room could be sufficiently lit after dark. We can also conclude that the light source must have been brought to the location when needed, a procedure that must have increased the risk of conflagration.

\section{THE QUALITY OF THE LIGHT}

Light is difficult to measure or evaluate; in fact it is possible to state that one can only evaluate the light conditions in a room by visiting it (Garnert 1993:28-31; Plummer 1997:16-17). Calculations can be made of course (Köhler 1959:131137), but this requires large amounts of information, which we lack in Pompeii despite the exceptional conditions of preservation.

\section{The dazzling light}

In the art of lighting a room, there is one factor that is essential for the perception of the surroundings - the human eye. The nature of the eye and the way it responds to light is vital for the experience of space. If the eye is directed straight into the unprotected flame or bright light, the effect of blinding is prominent and the areas around the light source will appear to be in darkness. This illustrates that, if 
the light source is too bright in contrast to the surroundings (dominance of luminance), the areas around will appear to be in shadow and the effect of the light source will be significantly reduced or eliminated (Köhler 1959:111-120, 124; Lam 1977:25, 38).

In a room with few openings, the contrast between the sunlight from the openings and the areas lying in shadow is razor-sharp. This condition was important for the finishing of the architecture of the doors and windows. If we look at the general appearance of windows, it appears as if a majority of them were constructed as niches with a large opening inwards, creating inward sloping surfaces on the inside (Mau 1908:207; Herbig 1929; Spinazzola 1953:65-80; Webster 1959; Ratzka 1990; Adam 1994:302-305. See further Harden 1974; Engle 1987; Broise 1991; Sperl 1990; Dwyer 1991; Baatz 1991:4-5; Gesemann 1996). The sides of the windows were used as reflection surfaces to spread the light into the room (Ratzka 1990:98), as seen in the different types presented by Spinazzola (Spinazzola 1953, figs. 68-71:77-82). Some of the Pompeian windows are the result of the reconstruction by the excavator, and further investigations are required.

I would like to suggest that the purpose of the sloping surfaces of the windows was not only to illuminate the room, but also to mediate the reaction of the eye by softening the transition between the brightly lit window and the dark massive walls around it. ${ }^{3}$ This soft transformation, from the bright sunlight of the open window to the shadow of the surrounding walls, makes the eye adjust to the light, and the differences in brightness can then be compensated. The sloping areas around the window function as transmitters of the light. If this softening is excluded, the bright light makes the surrounding surfaces appear as though in darkness and the room appears to be darker than in fact it is. In open doors the deep door-frames acted as surfaces for reflection and light-softening areas.

The blinding effect is less significant with regard to open flames, but it is still important to take into consideration. The light from an oil lamp is characterised by the open flame, the flickering light of the globe that surrounds it and the marked shadow cast by the body of the lamp (Held 1990:53-54; Garnert 1993:5458). This is, of course, a far less intensive light than sunlight. The light was both less distinct and less well spread in a room; the lamps are movable, however, and could be placed where light was required for the moment. As we have seen, bright smokeless light could only be produced by increasing the number of lamps or the number of nozzles on each lamp. The increasing number of open flames must have affected the eye as described above, and thus the same problem as with direct sunlight occurs. The use of high candelabra can be one way of dealing with this problem - by placing the oil lamp at a high point in the room, the light is less bright but more efficiently distributed around the room, and the open flame is moved out of the line of eyesight.

\footnotetext{
${ }^{3}$ I am most grateful to Helene Johansson, light designer, for drawing my attention to this effect.
} 


\section{Reflections on the surface}

There are other important remarks to make concerning the distribution of light in a room. We can call it 'the economics of light' or 'how to distribute a small amount of light to a larger space' - that is, how the light was made as efficient as possible.

The colour arrangements and decoration in rooms and atria changed through the centuries in what has been described as a matter of taste. The pros and cons of the system of classification (Mau 1882) have been discussed by scholars ever since. However, with respect to light distribution it is important to note that the surfaces of the frescoes were polished, a technique intended to protect the surface from damage and to preserve the colours (Adam 1994:221-223).

In her study of Casa della Caccia antica, Penelope Allison has put forth a suggestion of correlation between the position of a room and its decoration. In small rooms, in connection to the atrium, light colours with small panels were used; more elaborated paintings occur in spaces of a more open character, and dark (usually black) colours around the ambulatories of the garden (Allison 1992).

Here, it is important to emphasise the function of the polish as a means to reflect and distribute light into and within the rooms. Ratzka states that dark frescoes absorbed large amounts of light (Ratzka 1990:96), and my point is that, even if the colours of the paintings were dark, the light was reflected in the polished surface and distributed into the room. The quality of the surface onto which the light fell is essential for the distribution of light.

Apart from this, Ratzka states that the use of mosaics in bright colours to reflect the light from the compluvium is common (Ratzka 1990:96), but black mosaics are as frequent as white, as well as cocciopesto (a material of crushed terracotta mixed with lime which gives it a red colour) and lavapesta (with lava instead of terracotta, with a grey colour) which is used for simpler floors. The Caupona (V 1,13), the 'bakery' (V 1,15) and the Tavern (V 1,20-21) all had cocciopesto or lavapesta floors. In the atrium of the 'bakery' we found traces of the glaze of the cocciopesto floor, which originally had been highly polished and must have had a high reflecting quality despite the dark red colour, functioning in the same manner as the polish on the walls.

It is important to point out that it was the quality of the surface of both walls and floors more than the colours used that determined the amount of light reflected. The colour of the background, on the other hand, tinted and absorbed spectra of the light and gave it different nuances.

Besides the effect of distributing light, I find it important to emphasise yet another function of the polished surfaces. In the confined spaces with one or several bright light sources, the reflections in the polished surface had the same effect of mellowing, softening and smoothing the light for the eye of the beholder as with the sloping surfaces of the windows. In this process of mellowing the light, few lamps could spread more light than an increased number could have done without the reflections in the surfaces. 
Apart from this, by reducing the number of light sources, the risk of conflagration was also significantly reduced. This is similar to the clustering of stationary fire installations described earlier - the areas where fire was used were kept to a minimum.

\section{LIGHT AND FIRE IN CONTEXT}

After discussing the distribution of fire and the use of artificial light in Insula V 1, we can return to the aspects of open and closed rooms. We have seen that sufficient natural light from large doors and windows contradicted the effort of producing and keeping the heat in a room, at the same time as stationary heat sources were placed at a distance from the habitation areas on the ground floor. The heating of the rooms on the ground floor was left to movable braziers, as the light sources were to oil lamps.

The artificially lighted rooms must be seen in this context. Both inlets for oxygen and outlets for smoke from the fire sources were necessary, and at the same time these openings generated draught which caused the light from oil lamps to flicker. The appearance of artificial light was a contrast to the bright daylight with its even distribution over the surfaces. In winter the indoor conditions must have changed radically due to the moisture and cold weather. The doors to the rooms were closed, and the need for artificial light increased.

Together with the reflections in the polished surfaces of the frescoes and the mosaic or cocciopesto floors, the light in the rooms must have been displayed in a spectrum of colour - giving the space a variety of changing hues, brightness, and shadows. If we watch the gloomy light of oil lamps on candelabra, at a high point above the floor, with the draught causing the light to flicker, emphasised by the reflections in the surfaces - then the light becomes translucent (Plummer 1997:16-17). This reveals important aspects of the character and change of light in the Roman living space during the year.

On the basis of these aspects of light, I would like to suggest that the appearance of space in a Roman atrium house changed in a randomly repeated pattern, affected by a number of factors not associated with architecture, but nonetheless essential for the appearance and perception of space. It was manifested in the quality of the light which was affected by the arrangements of doors and windows, the colours and quality of the walls and floors, and last but not least, the weather, the daytime and the season.

In this article I would like to add the quality of light as an important factor in the creation and perception of space. The appearance of the room changed with the different conditions of light, during the day and night and during the changes in seasons, giving each area an ever-changing appearance. We could also say that under these conditions the space perceived as a room was experienced as 'smaller' when darkness fell.

This is an aspect of the design of the Roman atrium house that should be further investigated; it is an important quality of the interior that we today, with 
electric light and only the dilapidated paintings of the ancient rooms, have difficulty to imagining.

\section{English revised by Laura Wrang.}

\section{REFERENCES}

Adam, J-P. 1994. Roman building: materials and techniques. Bloomington \& Indianapolis.

Allison. P.M. 2004. Pompeian Households. An analysis of material culture. Cotsen Institute of Archaeology, Monograph, 42. Los Angeles.

Allison, P.M. 1999. Labels for ladles: Interpreting the material culture of Roman household. In: Allison, P.M. (Ed). The archaeology of household activities. Pp. 57-77. London \& New York.

Allison, P.M. 1992. The relationship between wall-decoration and room-type in Pompeian houses: a case study of the Casa della Caccia Antica. JRA. Vol. 5. Pp. 235-49.

Baatz, D. 1991. Fensterglastypen, Glasfenster und Architektur. In: Hoffmann, A. et al. (Eds). Bautechnik der Antike. Internationales Kolloquium in Berlin vom 15.-17. Februar 1990. Diskussionen zur Archäologischen Bauforschung, Band 5. Mainz. Pp. 4-13.

Bailey, D.M. 1972. Greek and Roman pottery Lamps. Oxford.

Bailey, D.M. 1978. Common Italian lamps - a brief guide. In: Blake, H. McK., Potter, T.W. \& Whitehouse, D.B. (Eds). Papers in Italian Archaeology I: the Lancaster Seminar: Recent research in prehistoric, classical and medieval archaeology. Part $i$. BAR. Supplementary series 41 (i). Pp. 243-249. Oxford.

Bailey, D.M. 1980. A catalogue of the lamps in the British Museum. II. Roman lamps made in Italy. London. Berry, J. 1997. Household artefacts: re-interpreting Roman domestic space. In: R. Laurence, R. \& WallaceHadrill, A. (Eds). Domestic space in the Roman world: Pompeii and beyond. JRA, Suppl. Series 22. Pp. 183-196. Portsmouth.

Bon, S.E. 1997. A city frozen in time or a site in perpetual motion? Formation processes at Pompeii. In: Bon S.E. \& Jonas, R. (Eds). Space and Sequence. Oxbow monographs 77. Pp. 7-12. Oxford

Brogan, J. 1997. Introduction in Light in architecture. Architectural design. Vol 67. Pp. 6-7.

Broise, H. 1991. Vitrages et volets des fenêtres thermales à l'époque impériale. In: Les thermes romains Actes de la table ronde, Rome 11-12 novembre 1988. Collection de l'École française de Rome 142. Pp. 61-78. Rome.

Cooley, A.E. 2003. Pompeii. London.

Cooley, A.E., \& Cooley, M.G.L. 2004. Pompeii: A sourcebook. London \& New York.

Curtis, R.I. 2001. Ancient food technology. Technology and change in history 5. Leiden \& Boston.

Descoeudres, J. 1993. Did some Pompeians return to their city after the eruption of Mt. Vesuvius in AD 79? In: Franchi Dell'Orto, L. (Ed). Ercolano 1738-1988. 250 anni di ricerca archeologica. Atti del Convegno internazionale Ravello-Ercolano-Napoli-Pompei, 30 ottobre - 5 novembre. 1988. Ministro per i beni culturali ed ambientali soprintendenza archeologica di Pompeii, Monographie 6. Pp. 165-178. Rome.

Dickmann, J.-A. 1997. The peristyle and the transformation of domestic space. In: Laurence, R. \& WallaceHadrill, A. (Eds). Domestic space in the Roman world: Pompeii and beyond, JRA, Suppl. Series 22. Pp. 121-136. Portsmouth.

Dwyer, E.J. 1982. Pompeian domsestic sculpture. A study of five Pompeian houses and their contents. Archaelogica 28. Rome.

Dwyer, E.J. 1991. The Roman atrium house in theory and practice. In: Gazda, E.K. \& Haeckl, A.E. (Eds). Roman art in the private sphere: new perspectives on the architecture and decor of the domus, villa, and insula. Pp. 25-48. Ann Arbor.

Engle, A. 1987. Light, Lamps and windows in antiquity. Readings in glass history no. 20. Jerusalem. 
Eschebach, L. (Ed). 1993. Gebäudeverzeichnis und Stadtplan der antiken Stadt Pompeji. Köln \& Weimar. Evans, E. 1978. A group of atrium houses without side rooms in Pompeii. In: Blake, McK. H, Potter, T.W. \& Whitehouse, D.B. (Eds). Papers in Italian archaeology I. The Lancaster Seminar. Recent research in prehistoric, classical and medieval archaeology, part $i$. BAR Supplementary Series 41 (i). Pp.175191.Oxford.

Faas, P. 2003. Around the Roman table. London.

Fiorelli, G. 1875. Descrizione di Pompei. Napoli.

Foss, P.W. 1994. Kitchens and dining rooms at Pompeii: the spatial and social relationship of cooking to eating in the Roman household. Ann Arbor.

Foss, P.W. 1997. Watchful Lares: Roman household organization and the rituals of cooking and dining. In: Laurence, R. \& Wallace-Hadrill, A. (Eds). Domestic space in the Roman world: Pompeii and beyond. JRA, Suppl. Series 22. Pp. 196-218. Portsmouth.

Frayn, J.M. 1978. Home-Baking in Roman Italy. Antiquity. Vol. 52. Pp. 28-33.

Garnert, J. 1993. Anden i lampan. Etnologiska perspektiv på ljus och mörker. Stockholm.

Gesemann, B. 1996. Die Strassen der antiken Stadt Pompeji. Entwicklung und Gestaltung. Europäische Hochschulschriften, Reihe 38, bd 56. Frankfurt am Main.

Grahame, M. 1997. Public and private in the Roman house: the Casa del Fauno. In: Laurence, R. \& WallaceHadrill, A. (Eds). Domestic space in the Roman world: Pompeii and beyond. JRA, Suppl. Series 22. Pp. 137-164. Portsmouth.

Harden, D.B. 1974. Window-glass from the Romano-British bath-house at Garden Hill, Hartfield, Sussex. AntJ. Vol. 54. Pp. 280-281.

Held, W. 1990. Künstliche Beleuchtung und Architektur. In: Heilmeyer W.-D. \& Hoepfner, W. (Eds). Licht und Architektur. Pp. 53-60. Tübingen.

Herbig, R. 1929. Fensterstudien an antiken Wohnbauten in Italien. RM. Vol. 44. Pp. 261-321.

Hermansen, G. 1974. The Roman inns and the law. The inns of Ostia. In: Evans, J.A.S. (Ed). Polis and imperium. Studies in honour of Edward Togo Salmon. Pp. 167-181. Toronto.

Hoffmann, A. 1980. Ein Beitrag zum Wohnen im vorrömischen Pompeji. Architectura. Vol. 10. Pp. 1-14.

Jansen, G. 1997. Private toilets at Pompeii: appearance and operation. In: Bon, S.E. \& Jones, R. (Eds) Sequence and space in Pompeii. Pp. 121-134. Oxford.

Jongman, W. 1988. The economy and society of Pompeii. Amsterdam.

Köhler, W. 1959. Lightning in architecture. Light and color as stereoplastic elements. New York.

Lam, W.M.C. 1977. Perception and lightning as formgivers for architecture. New York.

Laurence, R. 1994. Roman Pompeii. Space and society. London \& New York.

Leach, E.W. 1997. Oechus by Ibycus: Investigating the vocabulary of the Roman House. In: Bon, S.E. \& Jones, R. (Eds). Sequence and space in Pompeii. Pp. 50-72. Oxford.

Mau, A. 1882. Geschichte der decorativen Wandmalerei in Pompeji. Berlin.

Mau, A. 1886. Su certi apparecchi nei pistrini di Pompei. RM. Vol. 1. Pp. 45-48.

Mau, A. 1908. Pompeji in Leben und Kunst. Leipzig.

Maiuri, A. 1950. Pompei e Ercolano. Fra case e abitanti . Padova.

Mayeske, B.J. 1972. Bakeries, bakers and bread at Pompeii: a study in social and economic history. Maryland.

Mayeske, B.J. 1979. Bakers, bakeshops, and bread: a social and economic study. In: Pompeii and the Vesuvian landscape: Papers of a symposium sponsored by The Archaeological Institute of America, Washington Society and the Smithsonian Institution, Washington D.C. 1979. Pp. 39-58.

McKay, A.G. 1975. Houses, villas and palaces in the Roman world. London.

Nappo, S. 1997. The urban transformation at Pompeii in the late $3^{\text {td }}$ and early $2^{\text {nd }}$ centuries B.C. In: Laurence, R. \& Wallace-Hadrill, A. (Eds). Domestic space in the Roman world: Pompeii and beyond. JRA, Suppl. Series 22. Pp. 91-120. Portsmouth.

Overbeck, J. \& Mau, A. 1884. Pompeji in seinen Gebäuden Altertümern und Kunstwerken. Leipzig.

Packer, J.E. 1975. Middle and lower class housing in Pompeii and Herculaneum: A preliminary survey. In: Andreae, B. \& Kyrieleis, H. (Eds). Neue Forschungen in Pompeji und den anderen vom Vesuvausbruch 79 n.Chr. verschütteten Städten. Pp. 133-142. Recklinghausen. 
Parisinou, E. 1998. Lighting practices in early Greece from the end of the Mycenaean world to the 7th century B.C. OxfJA . Vol. 17. Pp. 327-343.

Perlzweig, J. 1961. Lamps of the Roman period: first to seventh century after Christ. The Athenian agora: results of excavations conducted by the American school of classical studies at Athens 7. Princeton.

Plummer, H. 1997. Building with light. In: Introduction in Light in architecture. Architectural design. Vol 67. Pp. 16-21.

Radt, W. 1986. Lampen und Beleuchtung in der Antike. $A W$. Vol. 17, Nr.1. Pp. 40-58.

Rasmussen, S.E. 1964. Experiencing architecture. Cambridge, MA.

Ratzka, Th. 1990. Atrium und Licht. In: Heilmeyer W.-D. \& Hoepfner, W. (Eds). Licht und Architektur. Pp. 95-106. Tübingen.

Rickman Fitch, C. \& Goldman, N.W. 1994. Cosa: the lamps. Memoirs of the American Academy in Rome 39. Ann Arbor.

Ring, J.W. 1996. Windows, baths, and solar energy in the Roman empire. AJA Vol. 100. Pp. 717-724.

Salza Prina Ricotti, E. 1978. Cucine e quartieri servili in epoca romana. RendPontAc. Vol. 51-52, 1978-80. Pp. 237-294.

Sperl, D. 1990. Glas und Licht in Architektur und Kunst. In: Heilmeyer W.-D. \& Hoepfner, W. (Eds). Licht und Architektur. Pp. 61-71. Tübingen.

Spinazzola, V. 1953. Pompei alla luce degli scavi nuovi di Via dell' Abbondanza (Anni 1910-23). Rome.

Strocka, V.M. 1991. Häuser in Pompeji. Bd 4, Casa del labirinto: (VI 11,8-10). Tübingen.

Wallace-Hadrill, A. 1997. Rethinking the Roman atrium house. In: Laurence, R. \& Wallace-Hadrill, A. (Eds). Domestic space in the Roman world: Pompeii and beyond. JRA, Suppl. Series 22. Pp. 219-240. Portsmouth.

Webster, G. 1959. Roman Windows and Grilles. Antiquity. Vol. 33 Pp. 10-14.

Yegül, F. 1992. Baths and bathing in classical antiquity. New York.

Zhuravlev, D\& Zhuravleva, N. 2002. Bosporian Late Hellenistic multi-nozzled lamps: a preliminary report. In: Zhuravlev D. (Ed). Fire, light and light equipment in the Graeco-Roman world. BAR Int. Ser 1019. Oxford.

\section{PERIODICA}

BdI Bullettino dell'Istituto di corrispondenza archeologica, Rome \& Berlin 1829-1885.

NSc Notizie degli scavi di antichità

GdS Giornale degli Scavi di Pompei, Nuovo Serie 1-4, 1868-1876.

CTP IIIA Corpus Topographicum Pompeianum, the insulae of Regions I-V, Rome 1986.

PPM Pompei: pitture e mosaici. Vol. 3. Giovanni Pugliese Carratelli (Ed). Roma 1991. 
